REAL APPLICATIONS OF ELECTRONIC SENSORS 
Titles in the Dimensions of Science Series

Chemical Engineering: Introductory Aspects R. J. Field Energy and Cells C. Gayford

Human Reproduction and in vitro Fertilisation H. J. Leese

Genes and Chromosomes J. R. Lloyd

Real Applications of Electronic Sensors G. Long

Physics and Astronomy D. McGillivray

Practical Ecology D. Slingsby and C. Cook

Ionic Organic Mechanisms C. Went

The Nature of Electrolyte Solutions M. Robson Wright 


\section{DIMENSIONS OF SCIENCE}

Series Editor: Professor Jeff Thompson
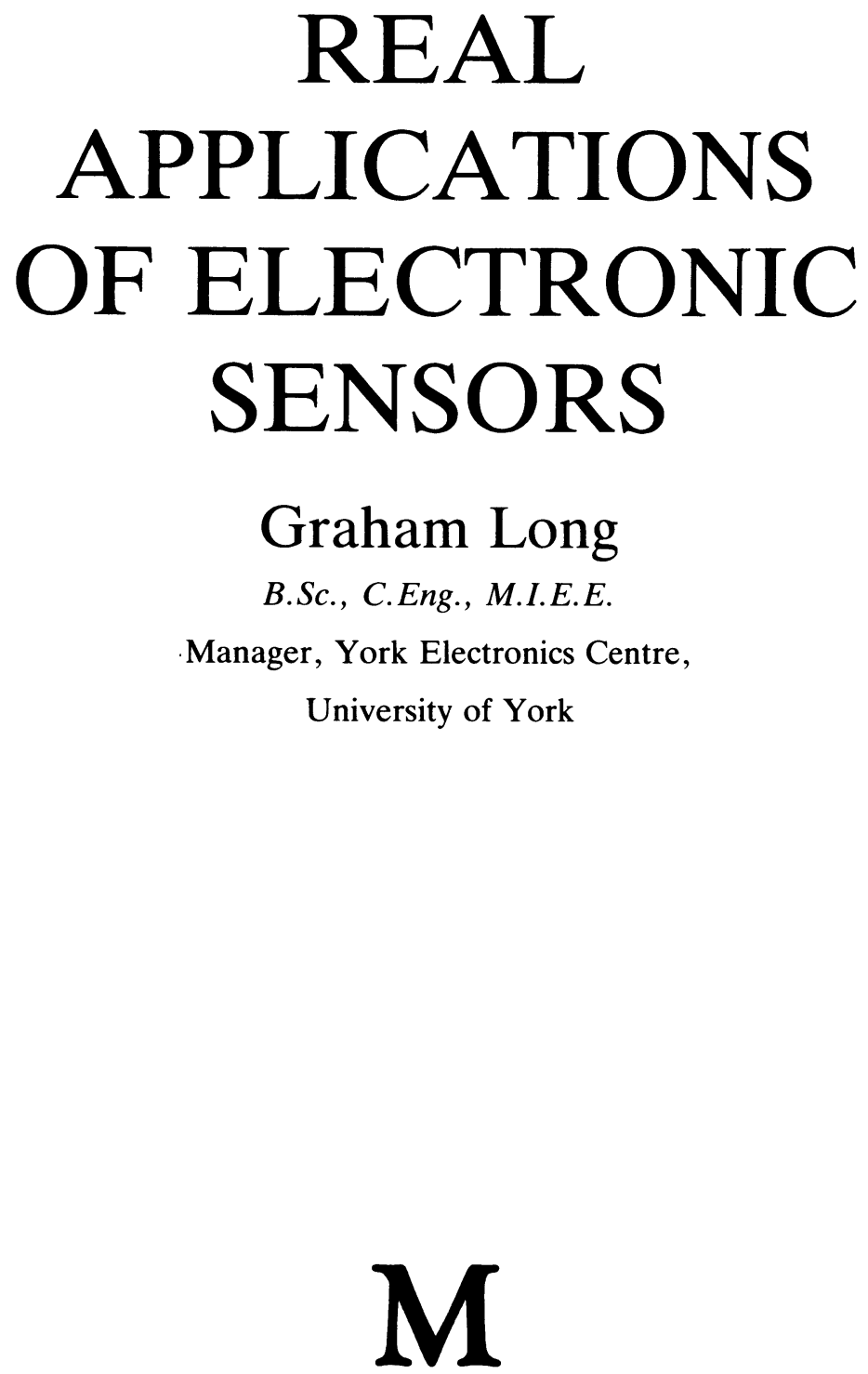

MACMILLAN

EDUCATION 
All rights reserved. No reproduction, copy or transmission of this publication may be made without written permission.

No paragraph of this publication may be reproduced, copied or transmitted save with written permission or in accordance with the provisions of the Copyright Act 1956 (as amended), or under the terms of any licence permitting limited copying issued by the Copyright Licensing Agency, 33-4 Alfred Place, London WC1E 7DP.

Any person who does any unauthorised act in relation to this publication may be liable to criminal prosecution and civil claims for damages.

First published 1989

Published by MACMILLAN EDUCATION LTD

Houndmills, Basingstoke, Hampshire RG21 2XS and London

Companies and representatives throughout the world

Typeset and Illustrated by TecSet Ltd, Wallington, Surrey

British Library Cataloguing in Publication Data Long, Graham

Real applications of electronic sensors.

1. Sensors. Applications

I. Title II. Series $620^{\prime} .0044$ 
To Fiona, Vicky, Alastair and Patrick

\section{Series Standing Order}

If you would like to receive future titles in this series as they are published, you can make use of our standing order facility. To place a standing order please contact your bookseller or, in case of difficulty, write to us at the address below with your name and address and the name of the series. Please state with which title you wish to begin your standing order. (If you live outside the United Kingdom we may not have the rights for your area, in which case we will forward your order to the publisher concerned.)

Customer Services Department, Macmillan Distribution Ltd Houndmills, Basingstoke, Hampshire, RG21 2XS, England. 


\section{Contents}

Series Editor's Preface ix

Acknowledgements $x$

1 Introduction 1

Brief coverage of the various elements used in the following application chapters - for example, resistor, capacitor, inductor, transformer, diode, photodiode, lens, mirror, prism, Hall effect device, thermocouple and piezoelectric device.

2 Potatoes and Diamonds

Proximity sensors, optical sizing, temperature control, swede topping, check weighing, crop spraying.

3 Making Shirt Buttons and Sewing Hems

Broken drill detection, hole sensing and counting, symmetry detector, crescent notch detector, hem sensor, fabric texture measurements.

4 Paper Making and Printing

Corrugated paper measurements, web break monitor, printing press tension control, synchronisation control for registration, registration of measuring tapes, minimising printing waste, checking felt tip pens.

5 Bottling Drinks and Food Inspection

Bottle fill detector, label detector, soft fruit and Brazil kernels inspection, checking for dirty bottles, egg albumen quality and shell colour measurement.

6 Chiropody, Dentistry and Other Applications

Toe nail bender, gum disease probe, pharmaceutical tablet inspection system, rate of cooling meter for biological specimens, 
electrical power monitor, fuel combustion sensing, shop window security, motor traffic sensors.

7 Basic Facts about Sensing Elements

More detailed description of the workings of sensing elements and some of the standard signal processing circuits.

8 Conclusion

Further Reading

Index 


\section{Series Editor's Preface}

This book is one in a Series designed to illustrate and explore a range of ways in which scientific knowledge is generated, and techniques are developed and applied. The volumes in this Series will certainly satisfy the needs of students at ' $A$ ' level and in first-year higher-education courses, although there is no intention to bridge any apparent gap in the transfer from secondary to tertiary stages. Indeed, the notion that a scientific education is both continuous and continuing is implicit in the approach which the authors have taken.

Working from a base of 'common core' ' $A$ '-level knowledge and principles, each book demonstrates how that knowledge and those principles can be extended in academic terms, and also how they are applied in a variety of contexts which give relevance to the study of the subject. The subject matter is developed both in depth (in intellectual terms) and in breadth (in relevance). A significant feature is the way in which each text makes explicit some aspect of the fundamental processes of science, or shows science, and scientists, 'in action'. In some cases this is made clear by highlighting the methods used by scientists in, for example, employing a systematic approach to the collection of information, or the setting up of an experiment. In other cases the treatment traces a series of related steps in the scientific process, such as investigation, hypothesising, evaluation and problem-solving. The fact that there are many dimensions to the creation of knowledge and to its application by scientists and technologists is the title and consistent theme of all the books in the Series.

The authors are all authorities in the fields in which they have written, and share a common interest in the enjoyment of their work in science. We feel sure that something of that satisfaction will be imparted to their readers in the continuing study of the subject. 


\section{Acknowledgements}

I would like to thank the following individuals and companies for not only giving permission for their product or process to be mentioned in this book but also for introducing me to many of the areas in which electronic sensors are used.

Mr R. M. Cowlin, Loctronic Graders Ltd

Mr A. Goff, British Button Industries Ltd

Mr P. Harkett, McCain Foods (UK) Ltd

Mr I Smith, Dekalb Inc.

Mr J. Prinz, Dextrodent Diagnostics Ltd

Mr R. Bannister, Burrow House Farm

Mr A. Vollans, Rigid Paper Products Ltd

Mr J. M. Shaw, Ben Shaws Ltd

Mr J. Atherton, Technical Services \& Supplies Ltd

Mr C. R. Ellis, Chiropodist

Dr A. Wilson, CCTR, University of York

Mr M. Scott, Eclipse Electrical Engineers Ltd

Mr A. Johnson, Electrical Contractor

Mr A. Tantrum, City Technology Ltd

Mr N. Helsby, Radiocode Clocks Ltd

Dr R. Millar, Department of Education, University of York

Dr L. Rogers, School of Education, University of Leicester

I would also like to thank David Morkill for his encouragement and helpful comments at the writing stage and my colleagues, past and present, in the Essex Electronics Centre, University of Essex, and in the York Electronics Centre, University of York, for all their creative work on many of the projects mentioned in this book. 